\title{
GROWTH-PRODUCTION PARAMETERS OF THE FIRST SLOVAK CULTIVAR OF FESTULOLIUM A. ET GR.
}

\author{
Peter Hric ${ }^{1}$ L'uboš Vozár ${ }^{1}$, Peter Kovár ${ }^{1}$ Juraj Hric ${ }^{2}$ \\ ${ }^{1}$ Department of Grassland Ecosystems and Forage Crops, Faculty of Agrobiology and Food Resources, Slovak \\ University of Agriculture in Nitra, Tr. A. Hlinku 2, 94976 Nitra, Slovak Republic \\ ${ }^{2}$ Graminex s.r.o., Okružná 13, 05401 Levoča, Slovak Republic
}

\begin{abstract}
HRIC PETER, VOZÁR L'UBOŠ, KOVÁR PETER, HRIC JURAJ. 2018. Growth-Production Parameters of the First Slovak Cultivar of Festulolium A. et Gr. Acta Universitatis Agriculturae et Silviculturae Mendelianae Brunensis, 66(3): 825-828.
\end{abstract}

The aim of this experiment was to compare growth and production parameters of the first Slovak cultivar of xFestulolium with Felina and Hykor. The experiment was conducted at the Demonstrating and research base of Department of Grassland Ecosystems and Forage Crops, Slovak Agricultural University in Nitra (Slovak Republic) with controlled moisture conditions (glass house) in 2017 (one year pot experiment). We compared new intergeneric hybrid Lenor with Felina and Hykor. In the experiment were evaluated average height $(\mathrm{mm})$ and dry matter (DM) yields (g). New intergeneric hybrid Lenor was in every cut highest $(\mathrm{P}<0.05)(59.57 \mathrm{~mm})$ in compare with controlled varieties Felina $(47.89 \mathrm{~mm}$ ) and Hykor $(47.07 \mathrm{~mm})$. Lenor had higher dry matter yields than Felina and Hykor in the first and second cut. In the $3^{\text {rd }}$ cut were not observed significant differences in dry matter yields. The highest DM yields were measured by Hykor $(2.82 \mathrm{~g})$. In sum of three cuts reached Lenor highest dry matter yield $(4.99 \mathrm{~g})$. This measured value was higher $(\mathrm{P}<0.05)$ compared with Felina's production.

Keywords: grasses, Festulolium, dry matter yields, height

\section{INTRODUCTION}

Grasses are important forage group with many valuable properties. From the perspective of fluency feeding fresh coarse fodder for livestock is valued production phytomass during most of growing season.

Festulolium A et Gr. is a natural or synthetic intergeneric hybrid between species of the genus Festuca L. and Lolium L. Breeding aim is cumulating positive, agricultural important, parents properties in the newly created genome. High yield potential and high quality fodder (higher content of water soluble sugars), shortening the vernalization and ear stage to next cuts are expected from genus Lolium L. High persistence, high yield, tolerance to climatic conditions (drought resistance) and resistance to diseases are expected from genus Festuca L.
(Casler et al., 2002; Humphreys et al., 2003; Cougnon, 2013; Černoch and Groenbaek, 2015). These properties of both types are associated in a given hybrid, in which is dominated by the properties of one of them. Hybrids accordingly divided into two groups. The first group consists of so called ryegrass type (Lolium L.) for example cv. Perun, Bečva and Lofa. Another group are consists of so called fescue type (Festuca L.) for example cv. Felina, Fojtan and Hykor (Kováč, 2002; Humphreys et al., 2003).

Hybrids have a broad spectrum uses. They are used in animal nutrition in the form of fresh phytomass, or as conserved fodder in the form of hay and haylage. Among other things, they can also be used like a biogas plants. Lolium x Festuca hybrids grass have good agronomical potential especially in adverse environments (Nesheim and Bronstad, 2000; Prochnow et al., 2009). 
The aim of this experiment was to compare growth and production parameters of the first Slovak cultivars of xFestulolium with Felina and Hykor.

\section{MATERIAL AND METHODS}

The experiment was established (sowed the seeds) on $21^{\text {st }}$ March 2017. It realized at the Demonstrating and research base of Department of Grassland Ecosystems and Forage Crops, Slovak Agricultural University in Nitra (Slovak republic) with controlled moisture conditions in 2017 (glass house). Weather conditions during monitored period are shown in Fig. 1.

We watched out 3 cultivars of Festulolium A. et Gr.: Festulolium A. et Gr. cv. Felina

Festulolium A. et Gr. cv. Hykor

Festulolium A. et Gr. cv. Lenor

Felina (registered in 1988) (Lolium multiflorum LAM. x Festuca arundinacea Schreb). created by crossing Lolium multiflorum LAM. cv. Rožňovský and Tiara with Festuca arundinacea Schreb. ecotypes from the neighbourhood Hladké Životice (Czech republic) and backcrossing with selected varieties of the world assortment. Hybrid Felina is first Czech variety of Festulolium A. et Gr. Felina is taller, persistent, resistant to frost and drought. It has a winter character. It is Festulolium pabulare and fescue type (Kováč et al., 2002).

Hykor (registered in 1991) (Lolium multiflorum LAM. X Festuca arundinacea Schreb.) created by crossing Lolium multiflorum LAM. cv. Rožňovský and Tiara with Festuca arundinacea Schreb. ecotypes from the neighbourhood Hladké Životice (Czech republic) and backcrossing with selected varieties of the world assortment. Hykor is resistant to freezes, drought and lie down. It is Festulolium pabulare and fescue type (Kováč et al., 2002).
Lenor (registered in 2015) (Lolium multiflorum LAM. $\mathrm{x}$ Festuca arundinacea Schreb.) created by crossing Lolium multiflorum LAM. cv. Jamaoba with Festuca arundinacea Schreb. cv. Sopline and backcrossing with selected varieties of the world assortment. Lenor is first Slovak variety of Festulolium A. et Gr. It has a rapid growth in the spring. Lenor is resistant to frost and drought. It has fine leaves and it is suitable for grazing. The breeder is Graminex s.r.o. Levoča (Slovak Republic). It is Festulolium pabulare and fescue type (Bašta, 2017).

Experiment was conducted in containers with volume $2 \mathrm{dm}^{3}$ in 3 replicates. Each container contained four individual seedlings $(n=12)$. Chemical characteristics of applied substrate are documented in Tab. I.

Grasses plants were fertilized at a dose of 100 kg.ha- ${ }^{-1} \mathrm{~N}$. The whole dose of fertilizer was divided for two equal doses $\left(2 \times 50 \mathrm{~kg} \cdot \mathrm{ha}^{-1} \mathrm{~N}\right)$. First fertilization was at 21 $1^{\text {st }}$ April 2017 (month after sowing) and second fertilization was done after the first mowing. Slovcerit fertilizer NPK (14-9-10) was used. The plants were irrigated at the first signs of water scarcity. Irrigation was with $200 \mathrm{ml}$ water on each container.

Grasses were cut with scissors to $50 \mathrm{~mm}$ on rowed plants on table. There were realized 3 mowing in terms $23^{\text {rd }}$ June, $14^{\text {th }}$ August and $27^{\text {th }}$ September 2017. Before each cut was determined height of grasses as an average of 3 measurements in each replication $(n=12)$. Moved aboveground phytomass was drying at $105{ }^{\circ} \mathrm{C}$ to constant weight. Then was measured a production. Dry matter (DM) yields were determined as the average of weights of phytomass from individual replicates.

The results were statistically evaluated by the Analysis of Variance (ANOVA - Multiple Range Tests, Method: 95.0 percent LSD) using statistical software STATISTICA 7.1 (Stat Soft. Inc. 2007).

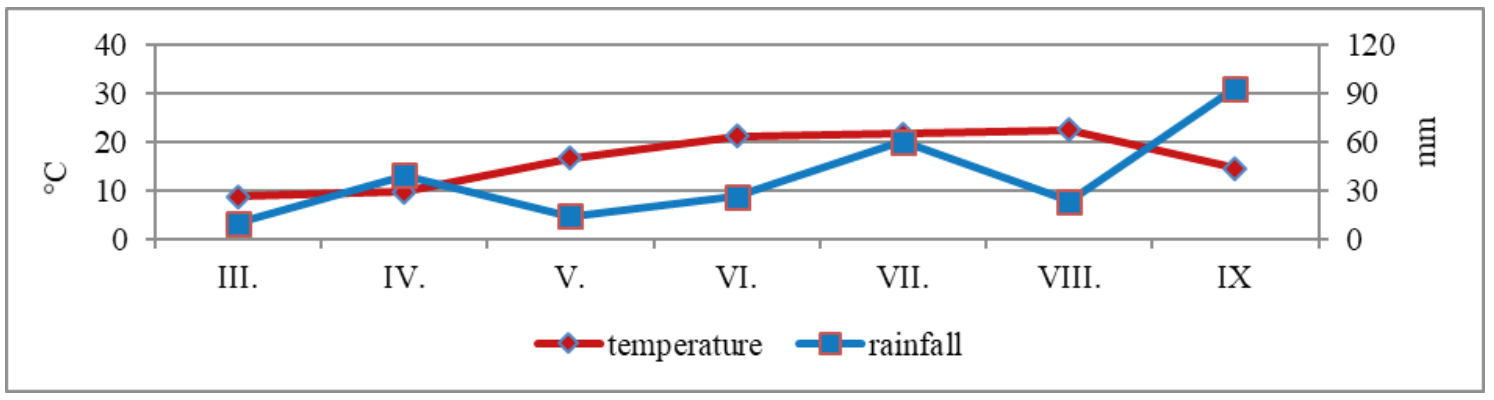

1: Average monthly temperature and rainfall in monitored period in 2017 Source: Department of Biometeorology and Hydrology, HLEF SUA in Nitra

I: Substrate agrochemical properties

\begin{tabular}{|c|c|c|c|c|c|c|c|c|}
\hline $\mathbf{N}_{\mathbf{t}}$ & $\mathbf{P}$ & $\mathbf{K}$ & $\mathrm{Ca}$ & $\mathrm{Na}$ & Mg & $\mathbf{F e}$ & $\mathrm{C}_{\mathrm{ox}}$ & \multirow{2}{*}{ pH } \\
\hline & & & mg.kg-1 & & & & g. $\mathrm{kg}^{-1}$ & \\
\hline 4067.07 & 71.53 & 538.78 & 6720 & 556.52 & 716.29 & 39.43 & 4.41 & 6.7 \\
\hline
\end{tabular}




\section{RESULTS AND DISCUSSION}

The average height of grass plants is presented in Tab. II. In the first cut was statistically significant higher Lenor $(72.56 \mathrm{~mm})$ as Felina $(51.77 \mathrm{~mm})$ and Hykor (54.28 mm). Bašta (2015) found out in state cultivar tests on first cut lowest the height Lenor as control cultivars Felina and Hykor. In the second cut was higher $(\mathrm{P}<0.05)$ Lenor $(59.00 \mathrm{~mm})$ as other cultivars (46.17 and $50.33 \mathrm{~mm}$ ) again. A similar trend as in the previous two cuts was detected on the last cut. Highest grass plants $(\mathrm{P}<0.05)$ were measured in a variety Lenor (47.17 $\mathrm{mm}$ ) compared with Hykor $(40.78 \mathrm{~mm})$ and Felina $(41.56 \mathrm{~mm})$. In the overall composition were highest plants $(\mathrm{P}<0.05)$ of the newly intergeneric hybrid Lenor $(59.57 \mathrm{~mm})$ as compared cultivars Felina (47.89 mm) and Hykor (47.07 mm).

Production of dry matter (DM) yields is given in Tab. III. In the first cut had Lenor higher dry matter yield (6.82 g) in compare with cultivars Felina (4.19 $\mathrm{g})$ and Hykor $(5.73 \mathrm{~g})$. The higher $\mathrm{DM}$ yield $(\mathrm{P}<0.05)$ of Lenor was in compare to Felina. Gáborčík and
Žibritová (2006) observed higher dry matter yield on the first cut of Hykor than Felina in field experiments with $x$ Fesulolium. Bašta (2015) found in state cultivar tests on first cut in Lenor about $7 \%$ lower DM yields as control cultivars Felina and Hykor. In the second cut was observed a similar tendency compared with the first cut. The highest dry matter yield was found by Lenor $(5.89 \mathrm{~g})$. Higher production $(\mathrm{P}<0.05)$ of the Lenor was in compare to Felina. In the last cut were not observed significant differences in dry matter yields. The highest DM yields had Hykor (2.82 g). In total evaluation had Lenor the highest DM yield (4.99 g). This measured value was higher $(\mathrm{P}<0.05)$ compared with Felina's production. Bašta (2015) found out in state cultivar tests that the variety Lenor had a 5\% lower dry matter yields as control varieties Felina and Hykor. In field experiments with xFestulolium Ježíková et al. (2000), Černoch et al. (2004), Boberfeld and Banzhaf (2006), Gutmane and Adomovics (2006), Gaborčík and Žibritová (2006) found out higher production of dry matter of Hykor than Felina. Rataj et al. (1997), Ilavská (1999), Houdek and Jambor (2010) reached the opposite conclusion.

II: The average height $(\mathrm{mm})$

\begin{tabular}{lccccccc}
\hline \multicolumn{1}{c}{ Cultivar } & $\mathbf{1}^{\text {st }}$ cut & SD & $\mathbf{2}^{\text {nd }}$ cut & SD & $3^{\text {rd }}$ cut & SD & Average of cuts \\
\hline Felina & $51.77^{\mathrm{a}}$ & \pm 1.98 & $50.33^{\mathrm{a}}$ & \pm 4.93 & $41.56^{\mathrm{a}}$ & \pm 0.95 & $47.89^{\mathrm{a}}$ \\
Hykor & $54.28^{\mathrm{a}}$ & \pm 2.64 & $46.17^{\mathrm{a}}$ & \pm 0.44 & $40.78^{\mathrm{a}}$ & \pm 0.63 & $47.07^{\mathrm{a}}$ \\
Lenor & $72.56^{\mathrm{b}}$ & \pm 2.91 & $59.00^{\mathrm{b}}$ & \pm 2.62 & $47.17^{\mathrm{b}}$ & \pm 3.69 & $59.57^{\mathrm{b}}$ \\
\hline
\end{tabular}

Different indexes (a, b) means statistically significant differences within column (Fisher LSD test, $\alpha=0.05$ ), $\mathrm{n}=12$, $\mathrm{SD}$ - standard deviation.

III: Dry matter yields (g)

\begin{tabular}{lccccccc}
\hline Cultivar & $\mathbf{1}^{\text {st }}$ cut & SD & $\mathbf{2}^{\text {nd }}$ cut & SD & $3^{\text {rd }}$ cut & SD & Average of cuts \\
\hline Felina & $4.19^{\mathrm{a}}$ & \pm 0.42 & $3.06^{\mathrm{a}}$ & \pm 1.37 & $1.88^{\mathrm{a}}$ & \pm 0.88 & $3.04^{\mathrm{a}}$ \\
Hykor & $5.73^{\mathrm{ab}}$ & \pm 0.96 & $4.73^{\mathrm{ab}}$ & \pm 0.66 & $2.82^{\mathrm{a}}$ & \pm 0.34 & $4.43^{\mathrm{ab}}$ \\
Lenor & $6.82^{\mathrm{b}}$ & \pm 1.00 & $5.89^{\mathrm{b}}$ & \pm 0.51 & $2.57^{\mathrm{a}}$ & \pm 0.31 & $4.99^{\mathrm{b}}$ \\
\hline
\end{tabular}

Different indexes (a, b) means statistically significant differences within column (Fisher LSD test, $\alpha=0.05$ ), $\mathrm{n}=12$, $\mathrm{SD}$ - standard deviation.

\section{CONCLUSION}

The submitted contribution evaluates growth and production capacity of first Slovak intergeneric hybrid Lenor with compared cultivars Felina and Hykor. Presented is one year container experiment. New intergeneric hybrid Lenor reached the highest $(\mathrm{P}<0.05)$ plant compared with Felina and Hykor. In total evaluation had Lenor the highest dry matter yield. This measured value was statistically higher compared with Felina's production.

Acknowledgements

We would like to thank Zuzana Podolinská and Ján Pečko for assistance in collecting the data.

\section{REFERENCES}

BAŠTA, L. 2015. Výsledky hospodárskej hodnoty odrody Lenor [in Slovak: The results of Lenor's profit value]. ÚKSUP: Bratislava.

BAŠTA, L. 2017. Nové odrody dateliny lúčnej a tráv. [New varieties of red clover and grasses]. Naše pole, 21(7): 26-27.

BOBERFELD, W. O. and BANZHAF, K. 2006. Yield and Forage Quality of Different $x$ Festulolium Cultivars in Winter. Journal of Agronomy and Crop Science, 192(4): 239-247. 
CASLER, M. D., PETERSON, P. R., HOFFMAN, L. D., EHLKE, N. J., BRUMMER, E. C., HANSEN, J. L., MLYNAREK, M. J., SULC, M. R., HENNING, J. C., UNDERSANDER, D. J., PITS, P. G., BILKEY, P. C. and ROSE-FRICKER, C. A. 2002. Natural selection for survival improves freezing tolerance, forage yield and persistence of Festulolium. Crop Science, 42: 1421-1426.

COUGNON, M. 2013. Potential in mixed swards and breeding of tal fescue. PhD Thesis, University Ghent.

ČERNOCH, V., HOUDEK, I. and CAPKA, R. 2004. Festulolium - grass for future. In: Bericht über die 55. Tagung 2004 der Vereinigung der Pflanzenzüchter und Saatgutkaufleute Österreichs. HBLFA Raumberg - Gumpenstein, 23. - 25. November 2004, pp. 87-89.

ČERNOCH, V. and GROENBAEK, O. 2015. Benefits of x Festulolium varieties in European agriculture. In: Proceedings of the $18^{\text {th }}$ Symposium of the European Grassland Federation Wageningen 15 - 17 June 2015. Wageningen Academic Publishers: Wageningen, pp. 386-388.

GABORČÍK, N. and ŽIBRITOVÁ, I. 2006. Produkčná schopnost' kostravy trstovitej (Festuca arundinacea Schreb.) a jej medzirodových hybridov I. Analýza produkčného porcesu a primárna produkcia. [in Slovak: Production capacity of tall fescue Festuca arundinacea Schreb.) and her intergeneric hybrids. I. Analysis of production process and primary production]. Acta fytotechnica et zootechnica, 9(1): 14-20.

GUTMANE, I. and ADAMOVICS, A. 2006. Productivity aspects of Festulolium and Lolium x boucheanum cultivars. In: Proceedings of the $21^{\text {st }}$ General Meeting of the European Grassland Federation vol. 11. Badajoz, Spain, 3-6 April 2006. Badajoz: Artes Gráficas Marcipa, pp. 155-157.

HOUDEK, I. and JAMBOR, V. 2010. Festulolium Hybrids from Breeding Station Hladké Životice and their Quality. In: Proceedings of the $17^{\text {th }}$ International Symposium of Forage Conservation, $17-19^{\text {th }}$ March, 2010 Mendel University Brno. UVPS: Brno, pp. 22-24.

HUMPHREYS, M. W., CANTER, P. J. and THOMAS, H. M. 2003. Advances in introgression technologies for precision breeding within the Lolium-Festuca complex. Annals of Applied Biology, 143(1): 1-10.

ILAVSKÁ, I. 1999. The comparison between the productivity of tall fescue and intergeneric grass hybrids under different utilization regimes in a mountain region. [in Slovak: Porovnanie produkčnej schopnosti kostravy trstenikovitej a medzirodových hybridov tráv v podmienkach horskej výrobnej oblasti v rôznych režimoch využívania]. Polnohospodárstvo (Agriculture), 45(9-10): 642-653.

JEŽÍKOVÁ, O., TOMAŠKIN, J. and REPISKÁ, J. 2000. Production and persistence of simple and complex grassclover mixtures. [in Slovak: Úrodnost'a vytrvalost' vybraných odrôd tráv a d'ateliny lúčnej v podhorskej oblasti]. Pol'nohospodárstvo (Agriculture), 46(2): 122-135.

KOVÁČ, L.. HOUDEK, I. and GEJGUŠ, J. 2002. The use of grass intergeneric hybrids in specific conditions of East Slovak lowland [in Slovak: Krmovinárske využitie rodových hybridov tráv v špecifických podmienkach Východoslovenskej ní̌iny]. Michalovce: Grafex.

NESHEIM, L. and BRONSTAD, I. 2000. Yield and winter hardiness of Festulolium (Festuca x Lolium) in Norway. Grassland Science in Europe, 5: 238-240.

PROCHNOW, A., HEIERMANN, M., PLOCHL, M., LINKE, B., IDLER, C. and AMON, T. Bioenergy from permanent grassland - a review: 1. Biogas. Bioresour Technol, 100(21): 4931-4944.

RATAJ, D., ILAVSKÁ, I., ŽILÁKOVÁ, J. and STREŽO, P. 1997. The function of intergeneric grass hybrids (Festulolium) in forage production of upland and mountain regions [in Slovak: Funkcia medzirodových hybridov tráv (Festulolium) v krmovinárstve horských a podhorských regiónov]. Polnohospodárstvo (Agriculture), 43(4-5): 252-263.

Peter Hric: peter.hric@uniag.sk

Contact information

Luboš Vozár: lubos.vozar@uniag.sk

Peter Kovár: peter.kovar@uniag.sk

Juraj Hric: j.hric@centrum.sk 